\title{
The Relationship between Transformational Leadership and Organizational Culture in National Oil Corporation of Libya
}

\author{
Adel Mohamed Ali Shurbagi ${ }^{1} \&$ Ibrahim Bin Zahari ${ }^{2}$ \\ ${ }^{1}$ Graduate School of Business, Universiti Tun Abdul Razak (UNIRAZAK), Malaysia \\ ${ }^{2}$ Graduate Business School, College of Graduate Studies, Universiti Tenaga Nasional (UNITEN), Malaysia \\ Correspondence: Adel Mohamed Ali Shurbagi, 17-4 pangaspuri puri permai putera, jalan 13 d, deas permai, taman \\ dato ahmed razali, 68000 ampang selangor, Malaysia. Tel: 60-1-7235-7484. E-mail: shurbagi@yahoo.com \\ Received: December 18, 2012 \\ Accepted: May 13, 2013 \\ Online Published: July 2, 2013 \\ doi:10.5430/ijba.v4n4p26 \\ URL: http://dx.doi.org/10.5430/ijba.v4n4p26
}

\begin{abstract}
The purpose of the study is to investigate the relationship between transformational leadership and organizational culture in National Oil Corporation of Libya. This research was carried out by measuring the data gathered from the five point likert scale. The Multifactor Leadership Questionnaire (MLQ) was used to measure transformational leadership, while the Organizational Culture Assessment Instrument (OCAI) was used to measure organizational culture. Quantitative survey method was applied and a sample of 227 employees of National Oil Corporation of Libya was selected to answer the instrument. SPSS software was used to analyze the data collected based on descriptive statistics (mean, standard deviation, percentage, Correlation and Regression). The empirical results indicate that the leaders of National Oil Corporation of Libya follow transformational leadership style to manage their organization, while the relationship between transformational leadership and organizational culture was positive significant relationship and Hierarchy culture was a dominant culture in NOC of Libya.
\end{abstract}

Keywords: Notational Oil Corporation of Libya, organizational culture, transformational leadership

\section{Introduction}

National Oil Corporation (NOC) of Libya was established in 1970 and it dominates Libya's oil industry, along with a number of smaller subsidiaries, which combined account for approximately half of the country's oil output. National Oil Corporation carries out exploration and production operations through its own affiliated companies, or in participation with other companies under service contracts or any other kind of petroleum investment agreements. This is in addition to marketing operations for oil and gas, locally as well as abroad. NOC has fully owned companies which carry out explorations, developments and production operations, in addition to local and international marketing companies (Sasi, 2008). NOC of Libya is a state-owned company that controls Libya's oil and gas production. The company is the biggest oil producer in Africa. its mandate is to promote the Libyan economy by undertaking development, management and exploitation of oil resources as well as by participating in planning and executing the general oil policy of the state (NationalOilCorporation, 2008). the choice of NOC of Libya to investigate the relationship between transformational leadership and organizational culture because Libya is a member of organization of petroleum exporting countries (OPEC) which holds the largest proven oil reserves and the most important oil producing countries in Africa and the world. The petroleum sector in Libya is very important because it is the backbone of Libyan economy. The research is approved by the university in order to examine the transformational leadership in Middle East in general and in petroleum sector in Libya in particular.

\subsection{Problem Statement}

The petroleum sector is the most important sector in Libya. Libya is one of the most important oil-producing countries in Africa and in the world, and that the interest in this sector is very important. Therefore, this sector needs professional's leaders who can achieve all the goals of both employees and organizations. An organization that is short of capital may resort to borrowing money, and one in a poor location has the option to move. However an organization with short of leadership has little chance for survival (Yousef, 1998).

The relationship between leadership and organizational culture has attracted considerable interest from both academics and practitioners. Much of the interest on these variables is based on the results of the previous studies which have 
asserted that these concepts may have an impact on the organizations performance (Suleiman, Azzawi, \& Jerjer, 2003 May; Yousef, 2001).

Furthermore, yet no study has been conducted to investigate the relationship between transformational leadership and organizational culture in petroleum sector in the Middle East in general or in Libya in particular. This study, therefore, is unique as it will help to fill this gap in an effort to improve the understanding of the role of leadership in NOC of Libyan setting. Based on the foregoing, the relationship between transformational leadership and organizational culture were not explored intensively enough in NOC of Libya.

\subsection{Research Objectives}

This paper has three objectives; the first aims to explore transformational leadership in NOC of Libya, the second aims to determine the nature of the relationship between transformational leadership and organizational culture in NOC of Libya, the third aims to determine the dominant culture in NOC of Libya. Based on the research objectives stated, the following research questions were addressed:

Q1. Does the manager of NOC of Libya follow transformational leadership style to manage their organization?

Q2. Is there any relationship between transformational leadership and organizational culture in NOC of Libya?

Q3. Which type of culture is dominating in NOC of Libya?

\section{Literature Review}

\subsection{Transformational Leadership}

The term of transformational leadership was created by the politologist, Burns, in 1978, but was subsequently developed by Bass and colleagues, until it reached its current importance (Avolio \& Yammarino, 2002; Bass, 1985). Transformational leaders are leaders who motivate followers via inspiration. The followers are offered challenges and support personality development. Concentration on the intangible qualities, such as shared ideas, shared values and vision in an effort to build up good relationships inside the organization (Bass, 1985).

According to (Bass, Avolio, Jung, \& Berson, 2003) the dimensions of transformational leadership are as following:

a. Idealized influence (attributed) the leader shares risks with subordinates and is consistent in behavior where ethics, principles, and values are concerned. The relationship between the leader and subordinates does not based on the formal institutional rules and regulations, rewards or punishments rather it is based on personal understanding.

b. Idealized influence (behavior) emphasizes on a collective sense of mission and values, as well as acting upon these values (Molero, Cuadrado, Navas, \& Morales, 2007).

c. Inspirational motivation leaders motivate and inspire those around them by providing the meaning and challenge to the followers' work.

d. Intellectual stimulation leaders stimulate the followers' efforts as innovative and creative by questioning assumptions, reframing problems, and approaching old situations in new ways.

e. Individualized consideration leaders pay special attention to each individual's needs for achievement and growth by acting as a coach or mentor.

\subsection{Organizational Culture}

In fact, the roots of organizational or corporate culture began in the mid nineteenth century (Blake \& Mouton, 1969) were the first authors who mentioned the link between organizational culture and excellence in the late 1960s. However, (Hofstede, 1998) pointed out that the concept of organizational culture has became a common parlance two decades after it was used by (Blake \& Mouton, 1969) as an aspect of the organization.

(Schein, 1992) defined organizational culture as a pattern of shared basic assumptions that the group has earned as it solved its problems of external adoption and internal integration that has worked well enough to be considered valid. Therefore, would be taught to the new members as the correct way to perceive, think and feel in relation to those problems. In this definition (Schein, 1992) also describes organizational culture as being deeper than behavior and artifacts.

\subsubsection{Types of Organizational Culture}

According to (Cameron \& Freeman, 1991; Quinn \& Cameron, 1983; Quinn \& Rohrbaugh, 1983) who ntroduced the Competing Values Framework (CVF), had identified four types of culture such as: clan, adhocracy, hierarchy and market culture. The theory of the Competing Values Framework (CVF) suggests two dimensions; the first dimension 
differentiates the effectiveness criteria that emphasize flexibility, discretion, and dynamism from the criteria that emphasize stability, order and control. The second dimension differentiates the effectiveness criteria that emphasize an internal orientation, integration and unity from the criteria that emphasize an external orientation, differentiation and rivalry.

The Competing Values Framework (CVF) of (Quinn \& Rohrbaugh, 1983) is very useful in organizing and interpreting a wide variety of organizational phenomena. (Cameron \& Quinn, 2006), from this theory, defined organizational culture as being taken for granted the values, underlying assumptions, expectations, collective memories and definitions present in organization. Each quadrant has been given a label to distinguish its most notable characteristics. Cameron and Quinn from this theory suggest four types of culture in organizations such as clan, adhocracy, hierarchy and market which illustrate in Figure 1.

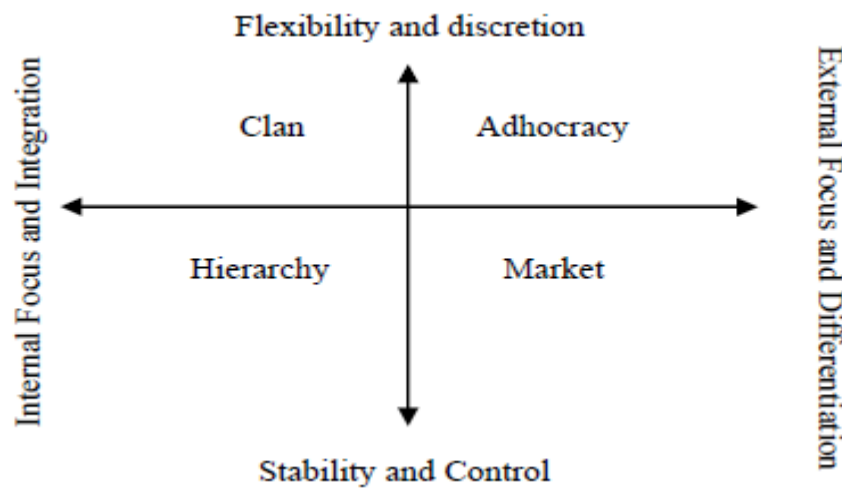

\subsubsection{Hierarchy Culture}

Figure 1. The competing values framework

According to (Cameron \& Quinn, 2006) the first introduce of the hierarchy culture by Weber consists of seven characteristics such as rules, specialization, meritocracy, hierarchy, separate ownership, impersonality, and accountability. These characteristics were deemed highly effective in the accomplishment of the purpose, and were adopted widely in organizations whose major challenge was to generate efficient, reliable, smooth flowing, and predictable output.

\subsubsection{Market Culture}

The term market is not similar to the marketing function or with consumers in the market place. Rather, it refers to a type of organization that functions as a market itself. It is oriented towards the external environment instead of internal affairs. It is focused on transactions with (mainly) external constituencies such as suppliers, customers, contractors, licensees, unions, and regulators. The market operates primarily through economic market mechanisms, mainly the monetary exchange. That is, the major focus of markets is to conduct transactions (exchange, sales, and contracts) with other constituencies to create a competitive advantage. Profitability, bottom-line results, strength in market niches, stretch targets, and secure customer bases are the primary objectives of the organization. Not surprisingly, the core values that dominate such market-type organizations are competitiveness and productivity. Competitiveness and productivity in the market organizations are achieved through the strong emphasis on external positioning and control.

\subsubsection{Clan Culture}

The term clan culture is used because of its similarity to a family-type organization. It seems more like extended families than economic entities. Instead of the rules and procedures of hierarchies or the competitive profit centers of markets, typical characteristics of clan-type firms were teamwork, employee involvement programs and corporate commitment to employees.

\subsubsection{Adhocracy Culture}

A major goal of the adhocracy culture is to foster adaptability, flexibility, and creativity where uncertainty, ambiguity, and information overload are typical. The adhocracy organization may frequently be found in industries such as aerospace, software development, think-tank consulting, and film making. An important challenge for these organizations is to produce innovative products and services and to adapt quickly to new opportunities. Unlike markets or hierarchies, adhocracies do not have a centralized power or an authority relationship. Instead, power flows from individual to individual or from task team to task team, depending on what problem is being addressed at the time 
(Cameron \& Quinn, 2006).

\section{Research Hypotheses}

Based on the literature review, research questions and research objectives the hypotheses of the study are as follow:

H1. The leaders of NOC of Libya follow transformational leadership style to manage their organization.

$\mathrm{H} 2$. There is a relationship between transformational leadership and organizational culture in NOC of Libya.

H3. The dominant culture in NOC of Libya is (Clan, Adhocracy, Market and Hierarchy) culture.

\subsection{Research Methodology}

To gather research data in the current study, questionnaire is preferred due to its ability to collect data from respondents within a limited time frame. The instrument consisted three parts such as demographic variables, transformational leadership and organizational culture.

\subsection{Instruments Measurement}

Two instruments were used to measure the variables of the study. These instruments are as following:-

\subsubsection{Multifactor Leadership Questionnaire (MLQ)}

The Multifactor Leadership Questionnaire (MLQ) was used to measure transformational leadership (Avolio \& Bass, 2004). This instrument has been revised several times and is widely used to measure transformational leadership in different countries in the world and the validity and reliability of this scale have been established through previous research (Hartog, Muijen, \& Koopman, 1997). Participants were asked to describe their supervisor's leadership behavior on 20 items based on transformational leadership. A five-point Likert scale was used with the responses ranging from ( $1=$ not at all; to $5=$ frequently, if not always). In the MLQ (Form5X), transformational leadership is measured via the use of the five dimensions of transformational leadership. The dimensions were measured by the four items for each, such as Intellectual Stimulation, Idealized Influence (behavior), Idealized Influence (attributed) Inspirational Motivation, and Individualized Consideration.

\subsubsection{Organizational Culture Assessment Instrument (OCAI)}

The Organizational Culture Assessment Instrument (OCAI) developed by (Cameron \& Quinn, 2006) as defined by the Competing Values Framework will be implemented in this study. The (OCAI) questionnaire was used to obtain an insight into the organizational culture based on the Organizational Culture Assessment Instrument (OCAI) which divided the organizational culture into four types namely, Clan, Adhocracy, Market and Hierarchy Culture.

This survey instrument requires the sample to respond to six key dimensions. According to (Cameron \& Quinn, 2006), the (OCAI) dimensions range from, dominant characteristics, organizational leadership, management of employees, organization glue, strategic emphasis and the criteria for success. Each of the six dimensions has four alternative answers which brings the total items of the (OCAI) questionnaire to 24 items. A Likert scale was used in which the respondents rate each alternative for each item on a scale from ( $1=$ strongly disagree; to $5=$ strongly agree). Therefore, the validity and reliability of Multifactor Leadership Questionnaire (MLQ) and The Organizational Culture Assessment Instrument (OCAI) scales have been established through previous research the Cronbach's Alpha coefficient of the instruments were above 0.70 (Al-Sharifi \& Al-Tanah, 2010; Twati \& Gammack, 2006). In the current study the Cronbach's Alpha coefficient of transformational leadership and organizational culture were 0.920 and 0.952 respectively.

\subsection{Participants}

To investigate the nature of the relationship between transformational leadership and organizational culture in NOC of Libya, out of (280) questionnaires were distributed with (250) returning. Of the (250) that returned, (23) questionnaires were rejected, due to insufficient data, resulting in (227) usable questionnaires yielding a response rate of $81 \%$. The stratified sample sampling was used in this study and the sample size has been chosen according to the population of NOC of Libya and the percentage of the employees in each administrative level then the sample was selected randomly. The data were then analyzed using Statistical Package for Social Sciences (SPSS). Details are given in Table 1.

Table 1. Questionnaires distributed

\begin{tabular}{ccccc}
\hline $\begin{array}{c}\text { Questionnaires } \\
\text { distributed }\end{array}$ & $\begin{array}{c}\text { questionnaires } \\
\text { returned }\end{array}$ & $\begin{array}{c}\text { Questionnaires } \\
\text { rejected }\end{array}$ & $\begin{array}{c}\text { Questionnaires } \\
\text { usable }\end{array}$ & Percent $\%$ \\
\hline 280 & 250 & 23 & 227 & 81 \\
\hline
\end{tabular}




\subsection{Empirical Results}

Data was analyzed through descriptive statistical methods with mean, standard deviation, percentage, Correlation Coefficient, and Regression. Table 2 contained profile of the respondents of the study. From the Table 2, it was obvious that the respondents between 36-45 years constitute majority of respondents with 104 (45.8\%) of the total of respondents while the least respondents with age range goes to those with less than 25 years 6 respondents (2.6\%). As mentioned earlier, the respondents for this study are employees in NOC of Libya, the majority of respondents hold Master degrees 77 (33.9\%), while 15 respondents (6.6\%) completed their PhD degree. 158 (69.6\%) of the respondents were married while only 69 respondents $(30.4 \%)$ were single. From total of 227 respondents from (NOC) of Libya indicate that, 168 of them (74\%) were male while the remaining was female. 89 respondents $(39.2 \%)$, reported that their income was $1101-1500$ DL monthly and only two respondents $(0.9 \%)$ their salary was more than 2300 DL monthly. From table 1.2 it can be seen that 46 of respondents $(20.3 \%)$ have working experiences with NOC of Libya for 11-15 years, only 25 of respondents (11.0\%) have working experiences in NOC of Libya for 1-5 years. Finally, the majority of respondents with $130(57.3 \%)$ of the total of respondents their boss's function was coordinator. This is followed by 63 respondents $(27.8 \%)$ who their boss's function was director. On the other hand, only 34 respondents (15\%) their boss's function was observer. All this information has given in Table 2.

Table 2. Profile of the respondents

\begin{tabular}{|c|c|c|}
\hline Contents & Frequency & Percent $\%$ \\
\hline \multicolumn{3}{|l|}{ Age } \\
\hline$<25$ years & 6 & 2.6 \\
\hline $26-35$ years & 53 & 23.3 \\
\hline 36 - 45 years & 104 & 45.8 \\
\hline $46-55$ years & 51 & 22.5 \\
\hline$>55$ years & 13 & 5.7 \\
\hline \multicolumn{3}{|l|}{ Educational level } \\
\hline Primary School & 10 & 4.4 \\
\hline Secondary School & 56 & 24.7 \\
\hline Degree & 69 & 30.4 \\
\hline Master Degree & 77 & 33.9 \\
\hline $\mathrm{PhD}$ & 15 & 6.6 \\
\hline \multicolumn{3}{|l|}{ Marital status } \\
\hline Single & 69 & 30.4 \\
\hline Married & 158 & 69.6 \\
\hline \multicolumn{3}{|l|}{ Gender } \\
\hline Male & 168 & 74 \\
\hline Female & 59 & 26 \\
\hline \multicolumn{3}{|l|}{ Income } \\
\hline$<700 \mathrm{DL}$ & 23 & 10.1 \\
\hline $701-1100 \mathrm{DL}$ & 48 & 21.1 \\
\hline $1101-1500 \mathrm{DL}$ & 89 & 39.2 \\
\hline $1501-1900 \mathrm{DL}$ & 58 & 25.6 \\
\hline $1901-2300 \mathrm{DL}$ & 7 & 3.1 \\
\hline$>2300 \mathrm{DL}$ & 2 & 0.9 \\
\hline \multicolumn{3}{|l|}{ Experience of Working } \\
\hline $1-5$ years & 25 & 11 \\
\hline $6-10$ years & 45 & 19.8 \\
\hline $11-15$ years & 46 & 20.3 \\
\hline $16-20$ years & 35 & 15.4 \\
\hline $21-25$ years & 33 & 14.5 \\
\hline$>25$ years & 43 & 18.9 \\
\hline \multicolumn{3}{|l|}{ Function of your boss } \\
\hline Coordinator & 130 & 57.3 \\
\hline Director & 63 & 27.8 \\
\hline Observer & 34 & 15 \\
\hline
\end{tabular}


Table 3 provided the percentages, means, and standard deviations related to the perceptions of respondents of the NOC of Libya about transformational leadership and organizational culture in their organization. According to Table 3, the respondents of the study asserted that the leaders of NOC of Libya follow transformational leadership to manage their organization. From the data the mean of the five dimensions of transformational leadership such as intellectual stimulation, idealized influence (behavior), idealized influence (attributed), inspirational motivation and individualized consideration were $3.25,3.48,3.50,3.38$ and 3.10 respectively, while the standard deviation of them were $0.849,0.866,0.881,0.786$ and 0.983 respectively. These findings supported the results of the previous studies which pointed out that the leaders of the organizations in Arabic countries follow transformational leadership to manage their organizations (AL-azmi, 2006; Al-Omari, 2004; Al-Sharifi \& Al-Tanah, 2010; Sabri, 2006; Suleiman, et al., 2003 May) these studies have been carried out in different sectors such as public sector, industry sector, education sector, and services sector while the current study has carried out in petroleum sector in Libya.

Table 3. Mean and standard deviation

\begin{tabular}{lll}
\hline Variable \& Dimensions & M & SD \\
\hline Transformational Leadership (TL) & 3.34 & 0.763 \\
\hline Intellectual Stimulation (IS) & 3.25 & 0.849 \\
\hline Idealized Influence (Behavior) (IIB) & 3.48 & 0.866 \\
\hline Idealized Influence (Attributed) (IIA) & 3.50 & 0.881 \\
\hline Inspirational Motivation (IM) & 3.38 & 0.786 \\
\hline Individualized Consideration) (IC) & 3.10 & 0.983 \\
\hline Organizational Culture (OC) & 2.84 & 0.731 \\
\hline Clan Culture (CC) & 2.88 & 0.893 \\
\hline Adhocracy Culture (AC) & 2.62 & 0.722 \\
\hline Market Culture (MC) & 2.85 & 0.772 \\
\hline Hierarchy Culture (HC) & 3.03 & 0.730
\end{tabular}

From the data the means of clan, adhocracy, market and hierarchy culture were $2.88,2.62,2.85$, and 3.03 respectively, while the standard deviations of them were $0.893,0.722,0.772$ and 0.730 respectively. Therefore, as can be seen from Table 3, the participants of NOC of Libya have pointed out that the dominant culture in the NOC of Libya was Hierarchy culture. This result consistent with previous studies by (Twati, 2006) who pointed out that the dominant culture in Banking and Oil sector in Libya was Hierarchy culture. (Cameron \& Quinn, 2006) argue that most organizations take turns at different cultures. As they progress from the start in a clan culture, they then move to adhocracy culture, then to market culture and finally to the hierarchy culture after they have been established for some time. NOC of Libya examined in this study was established in the early 1970s, which mean that they fit in the hierarchy culture at this point. From discussion above and Table 3, it could be concluded that the leaders of NOC of Libya follow transformational leadership style to manage their organization while the dominant culture in NOC of Libya is Hierarchy culture. Table 3 summarizes the mean and standard deviation of the variables.

Cronbach Coefficient Alpha was used to test the reliability of the instruments Sekaran (2005) pointed out that Cronbach Coefficient Alpha of 0.70 or more are considered good. The Cronbach's alpha reliability coefficients for the transformational leadership and organizational culture were 0.920 and 0.952 respectively. Based on the Cronbach Alpha values for five dimensions of transformational leadership and four types of organizational culture the instruments are reliable to measure the variables of the study. Table 4 summarizes the reliability of the instrument used in the study.

Table 4. Reliability of the instrument of the study

\begin{tabular}{|c|c|c|c|}
\hline Variable or dimensions & $\begin{array}{c}\text { Number } \\
\text { of items }\end{array}$ & $\begin{array}{c}\text { Cronbach } \\
\text { Alpha }\end{array}$ & \\
\hline Intellectual Stimulation (IS) & 4 & 0.820 & \\
\hline Idealized Influence (behavior) (IIB) & 4 & 0.882 & \\
\hline Idealized Influence (attributed) (IIA) & 4 & 0.882 & \\
\hline Inspirational Motivation (IM) & 4 & 0.877 & \\
\hline Individualized Consideration) (IC) & 4 & 0.884 & \\
\hline Transformational leadership (TL) & 20 & & 0.920 \\
\hline Clan Culture (CC) & 6 & 0.897 & \\
\hline Adhocracy Culture (AC) & 6 & 0.855 & \\
\hline Market Culture (MC) & 6 & 0.856 & \\
\hline Hierarchy Culture (HC) & 6 & 0.840 & \\
\hline Organizational Culture (OC) & 24 & & 0.952 \\
\hline
\end{tabular}


To study the correlation between variables, correlation was selected to investigate the correlation between these variables. It's clear from Table 5, that the relationship between transformational leadership and organizational culture is a strong and positive relationship with correlation coefficient of 0.678 at 0.01 level. On the same line, based on the result of correlation the relationship between five dimensions of transformational leadership and four types of organizational culture was positive and significant relationship at 0.01 level. Therefore, the highest correlation between the five dimensions of transformational leadership and four types of organizational culture was found between Individualized Consideration (IC) and Adhocracy Culture (AC), $\mathrm{r}=0.653$. While, the weakest correlation was found between inspiration motivation (IM) and market culture (MC), $r=0.444$ and all the correlation at 0.01 level. Details have given in table below. Based on the results of the correlation between the variables of the study and their dimensions it could be concluded that the relationship between transformational leadership and organizational culture was significant positive relationship. These results are consistent with previous studies which carried out by (Flemming, 2009; Hu, Yang, \& Islam, 2009; Rad \& Yarmohammadian, 2006; Yousef, 2000) who concluded that the relationship between transformational leadership and organizational culture was positive and significant relationship. Table 5 summarizes the results of correlation.

Table 5. Correlation

\begin{tabular}{|c|c|c|c|c|c|c|c|c|c|c|c|}
\hline & IS & IIB & IIA & IM & IC & TL & $\mathrm{CC}$ & $\mathrm{AC}$ & $\mathrm{MC}$ & $\mathrm{HC}$ & $\mathrm{OC}$ \\
\hline IS & 1 & $0.672^{* *}$ & $0.650^{* *}$ & $0.585^{* *}$ & $0.696^{* *}$ & $0.825^{* *}$ & $0.496^{* *}$ & $0.594^{* *}$ & $0.528^{* *}$ & $0.517^{* *}$ & $0.566^{* *}$ \\
\hline IIB & & 1 & $0.854^{* *}$ & $0.652^{* *}$ & $0.774^{* *}$ & $0.908^{* *}$ & $0.640^{* *}$ & $0.621^{* *}$ & $0.635^{* *}$ & $0.570^{* *}$ & $0.658^{* *}$ \\
\hline IIA & & & 1 & $0.650^{* *}$ & $0.775^{* *}$ & $0.904^{* *}$ & $0.557^{* *}$ & $0.571^{* *}$ & $0.594^{* *}$ & $0.535^{* *}$ & $0.601^{* *}$ \\
\hline IM & & & & 1 & $0.678^{* *}$ & $0.810^{* *}$ & $0.451^{* *}$ & $0.457^{* *}$ & $0.444^{* *}$ & $0.460^{* *}$ & $0.482^{* *}$ \\
\hline IC & & & & & 1 & $0.907^{* *}$ & $0.593^{* *}$ & $0.653^{* *}$ & $0.601^{* *}$ & $0.546^{* *}$ & $0.637^{* *}$ \\
\hline TL & & & & & & 1 & $0.630^{* *}$ & $0.668^{* *}$ & $0.646^{* *}$ & $0.604^{* *}$ & $0.678^{* *}$ \\
\hline $\mathrm{CC}$ & & & & & & & 1 & $0.855^{* *}$ & $0.901^{* *}$ & $0.827^{* *}$ & $0.960^{* *}$ \\
\hline $\mathrm{AC}$ & & & & & & & & 1 & $0.850^{* *}$ & $0.757^{* *}$ & $0.921^{* *}$ \\
\hline $\mathrm{MC}$ & & & & & & & & & 1 & $0.839^{* *}$ & $0.958^{* *}$ \\
\hline $\mathrm{HC}$ & & & & & & & & & & 1 & $0.910^{* *}$ \\
\hline OC & & & & & & & & & & & 1 \\
\hline
\end{tabular}

3.5 Hypotheses Testing

To test the hypotheses of the study Regression analysis was used to test the hypotheses of the study. These hypotheses examine the relationship between transformational leadership and organizational culture. From Table 6 the result of linear regression indicates that that (transformational leadership) has contributed significantly in the variability of (organizational culture) by $46 \%$ from the total variability. Regression coefficients were found to be significant for transformational leadership and organizational culture, and that could be confirmed by their respective $t$ statistics and p-value. By looking at the beta coefficient for organizational culture can determine the relationship between transformational leadership and organizational culture. The regression model implied in this study was found statistically significant (P-value $<0.05$ ). These findings could be suggested that the model was able to fit the data. On the other hand, it could be concluded that the relationship between transformational leadership and organizational culture is a positive relationship. Table 6 summarizes the results of Regression Analysis.

Table 6. Regression analysis

\begin{tabular}{cccccc}
\hline $\mathrm{R}$ & \multicolumn{2}{c}{ R Square } & R Square & \multicolumn{2}{c}{ Std. Error of the Estimate } \\
\hline 0.678 & \multicolumn{2}{c}{0.460} & 0.458 & \multicolumn{2}{c}{0.539} \\
\hline & Unstandardized & & Standardized & & \\
\hline B & Std. Error & Beta & $\mathrm{t}$ & P-value \\
\hline (Constant) & 0.673 & 0.161 & & 4.174 & 0.000 \\
\hline TL & 0.651 & 0.047 & 0.678 & 13.843 & 0.000 \\
\hline
\end{tabular}




\section{Conclusion}

The purpose of this study is to investigate the relationship between transformational leadership and organizational culture in National Oil Corporation of Libya. By using questionnaires, data was gathered from 227 employees of NOC of Libya. Data on the respondents' transformational leadership and organizational culture were collected using Multifactor Leadership Questionnaire (MLQ) developed by Avolio \& Bass (2004) and The Organizational Culture Assessment Instrument (OCAI) developed by (Cameron \& Quinn, 2006) respectively. Descriptive statistics were reported, followed by mean, standard deviation, reliability analysis, Correlation and hypotheses testing using Regression analysis. From the current study it could be concluded that the leaders of National Oil Corporation in Libya follow transformational leadership style to manage their organization and the relationship between transformational leadership and organizational culture was positive and significant relationship while the dominant culture in NOC of Libya was Hierarchy culture.

\section{References}

AL-azmi, M. B. (2006). Transference leadership and its relation with managerial creative: surveying study on civil employees department ministry of interior. Unpublished master's thesis, Naif Arab University, Saudi Arabia.

Al-Omari, M. N. (2004). The relationship between the characteristics of transformational leadership and the availability of the principles of Total Quality Management. Unpublished master's thesis, King Saud University, Riyadh.

Al-Sharifi, A. M., \& Al-Tanah, M. M. (2010). The degree of practicing transformational leadership by private secondary school principals in the UAE. Journal of Human Sciences, 45(7), 1-28.

Avolio, B. J., \& Bass, B. M. (2004). Multifactor leadership questionnaire: manual and sampler set. Mind Garden, Inc.

Avolio, B. J., \& Yammarino, F. J. (2002). Transformational and charismatic leadership: The road ahead: The road ahead. New York: Erlbaum.

Bass, B. M. (1985). Leadership and performance beyond expectations. Free Press.

Bass, B. M., Avolio, B. J., Jung, D. I., \& Berson, Y. (2003). Predicting unit performance by assessing transformational and transactional leadership. Journal of applied psychology, 88(2), 207. http://dx.doi.org/10.1037/0021-9010.88.2.207

Blake, R. R., \& Mouton, J. S. (1969). Building a Dynamic Corporation through Grid Organization Development: Addison-Wesley.

Cameron, K. S., \& Freeman, S. J. (1991). Cultural congruence, strength, and type: Relationships to effectiveness. Research in organizational change and development, 5(1), 23-58.

Cameron, K. S., \& Quinn, R. E. (2006). Diagnosing and changing organizational culture: Based on the competing values framework. Jossey-Bass.

Flemming, P. L. (2009). A study of the relationship between transformational leadership traits and organizational culture types in improving performance in public sector organizations: A Caribbean perspective. Unpublished doctoral dissertation, Capella University, USA.

Hartog, D. N., Muijen, J. J., \& Koopman, P. L. (1997). Transactional versus transformational leadership: An analysis of the MLQ. Journal of occupational and organizational psychology, $70(1), \quad 19-34$. http://dx.doi.org/10.1111/j.2044-8325.1997.tb00628.x

Hofstede, G. (1998). Attitudes, values and organizational culture: Disentangling the concepts. Organization studies, 19(3), 477-492. http://dx.doi.org/10.1177/017084069801900305

Hu, Y. J., Yang, Y. F., \& Islam, M. (2009). Leadership behavior, satisfaction, and the balanced scorecard approach: An empirical investigation of the manager-employee relationship at retail institutions in Taiwan. International Journal of Commerce and Management, 20(4), 339-356. http://dx.doi.org/10.1108/10569211011094659

Molero, F., Cuadrado, I., Navas, M., \& Morales, J. (2007). Relations and effects of transformational leadership: a comparative analysis with traditional leadership styles. The Spanish journal of psychology, 10(2), 358-368.

NationalOilCorporation. (2008). Gale directory of company histories: National Oil Corporation. Retrieved 10 February, 2010, from http://www.answers.com/topic/national-oil-corporation

Quinn, R. E., \& Cameron, K. (1983). Organizational life cycles and shifting criteria of effectiveness: Some preliminary evidence. Management science, 29(1), 33-51. http://dx.doi.org/10.1287/mnsc.29.1.33 
Quinn, R. E., \& Rohrbaugh, J. (1983). A spatial model of effectiveness criteria: Towards a competing values approach to organizational analysis. Management science, 29(3), 363-377. http://dx.doi.org/10.1287/mnsc.29.3.363

Rad, A. M. M., \& Yarmohammadian, M. H. (2006). A study of relationship between managers' leadership style and employees' job satisfaction. Leadership in Health Services, 19(2), 11-28. http://dx.doi.org/10.1108/13660750610665008

Sabri, H. A. (2006). Leadership styles dominant and the requirements shift to the Knowledge Economy. Zaytoonah University of Jordan, 1-22.

Sasi, T. A. (2008). Antecedents of human resource management practices: Case study analyses of the National Oil Corporation in Libya. Unpublished doctoral dissertation, Tun Abdul Razak University. Kuala Lumpur.

Schein, E. H. (1992). Organizational culture and leadership. Jossey-Bass San Francisco.

Suleiman, M. M. S., Azzawi, M. A. M., \& Jerjer, A. M. S. (2003, May). The impact of dimensions of transformational leadership in the management of organizational change. Paper presented at the International Scientific Conference of the eighth annual Change management and knowledge society, Mosul, Iraq.

Twati, J. M. (2006). Societal and organisational culture and the adoption of management information systems in Arab countries. Unpublished doctoral dissertation, Griffith University, Australia.

Twati, J. M., \& Gammack, J. G. (2006). The impact of organisational culture innovation on the adoption of IS/IT: the case of Libya. Journal of enterprise information management, 19(2), 175-191. http://dx.doi.org/10.1108/17410390610645076

Yousef, D. A. (1998). Correlates of perceived leadership style in a culturally mixed environment. Leadership \& Organization Development Journal, 19(5), 275-284. http://dx.doi.org/10.1108/01437739810234341

Yousef, D. A. (2000). Organizational commitment: a mediator of the relationships of leadership behavior with job satisfaction and performance in a non-western country. Journal of Managerial Psychology, 15(1), 6-24. http://dx.doi.org/10.1108/02683940010305270

Yousef, D. A. (2001). Islamic work ethic: A moderator between organizational commitment and job satisfaction in a cross-cultural context. Personnel Review, 30(2), 152-169. http://dx.doi.org/10.1108/00483480110380325 